\title{
Kearifan Menyikapi Liberalisasi Pendidikan
}

\author{
Pambudi M. Jalal
}

The economy aspect will influence on education management. The education management should accomodate the market trends, and its trends toward profit taking.Thus, the changing of this orientation is afraid of some educators because this will ignore the main goal of education, namely to protect Indonesians and the whole of Indonesian archipelago, to develop the public welfare, to educate this nation, and to participate in realizing world order. If this happens, the indentity and the ideology of Indonesia can not be reached because of education liberalization. This will imply the ideology and morality destruction.

\section{Kata Kunci: Kearifan, Liberalisasi, Pendidikan, Ideologi, Nasional}

$E$ ra perdagangan bebas (free trade zone), memaksa kita berhadapan dengan liberalisasi dan globalisasi. Persoalan ini menimbülkan kekhawatiran berbagai kalangan. Alasannya, di satu sisi kita harus membuka diri dan menerima kemajuan dunia luar, akan tetapi di sisi lain kita dihadapkan pada minimnya atau lemahnya sumber daya manusia (SDM). Dua faktor tersebut menimbulkan pro-kontra tentang keikutsertaan kita dalam era perdagangan bebas yang dianggap terlalu cepat. Dengan ditandatanganinya GATS (the General Agreement on Trade in Service), perjanjian kerja sama multinasional ini, setiap negara diberi kesempatan untuk mengajukan berbagai jenis jasa, yang bisa dibuka untuk diperdagangkan secara bebas. Salah satu yang akan diliberalisasi adalah pendidikan.

Pencantuman pendidikan sebagai salah satu jenis jasa yang akan diliberalisasi, menimbulkan kekhawatiran di kalangan pendidik. Adanya penolakan kalangan perguruan tinggi, yang diwakili oleh Forum Rektor Indonesia (FRI), membuktikan liberalisasi pendidikan belum bisa diterima seutuhnya, mengingat pendidikan bukan hanya merupakan proses transfer ilmu pengetahuan, akan tetapi di dalamnya terdapat proses pembentukan ideologi dan karakter bangsa. Ketika pendidikan kita diserahkan pada pihak asing, maka akan terjadi dualisme kepentingan. Pertama, peranan aspek ekonomi.

Kedua, orientasi (tujuan) pendidikan itu sendiri, sehingga dikhawatirkan pendidikan akan mengabaikan pola pembentukan karakter bangsa, sebagaimana tercantum dalam Undang-Undang Dasar 1945.

Dari sekian banyak permasalahan yang akan timbul, setidaknya ada tiga permasalahan yang menonjol dari liberalisasi pendidikan.

Pertama, benturan budaya. Ketika pendidikan diserahkan pada pihak asing, maka secara langsung pengaruh budaya luar akan tereduksi dalam dunia pendidikan. 
Dan, yang paling parah kalau sampai masuk dalam kehidupan masyarakat kita, sehingga akan menjadi kontra produktif, yang akhirnya budaya asli kita terisolasi oleh budaya asing.

Banyak kasus terjadi saat ini, seperti kehidupan seks bebas (free sex) di kalangan remaja, narkoba dan kejahatan kemanusiaan lainnya. Hal ini disebabkan mudahnya budaya asing masuk dalam tatanan kehidupan masyarakat kita, alih-alih modernisasi. Dan akhirnya, kehidupan masyarakat kita terperangkap dalam budaya asing, yang tidak sesuai dengan norma-norma dan akarbudaya bangsa. Tanpa adanya liberalisasi pendidikan saja, kebudayaan kita sudah terkontaminasi, apalagi jika liberalisasi diberlakukan. Inilah salah satu bentuk kehawatiran masyarakat.

Kedua, polarisasi ideologi. Ideologi merupakan-jati-diri atau karakter süatu bangsa, ideologi memberi karakter dan pengaruh bagi bangsa dalam pergaulan dunia internasional. Ketika terjadi liberalisasi dalam pendidikan kita, faham atau ideologi asing akan dengan mudah masuk dalam kehidupan bangsa kita, sehingga pendidikan kita akan mengikuti faham asing tanpa bisa kita cegah. Masuknya ideologi asing, secara tidak langsung akan merubah tatanan kehidupan dan sistem berpikir masyarakat. Berbagai bentuk pemikiran saat ini telah berkembang sedemikian rupa, sehingga mewarnai sistem kehidupan bangsa, mulai dari penganut faham konservatif, sosialisme, marxisme hingga radikalisme, berbaur menjadi satu dalam kehidupan masyarakat. Sehingga terkadang, menimbulkan konflik horizontal dalam masyarakat. Kebebasan berfikir tidak menjadi tabu dan haram, akan tetapi ketika kebebasan tersebut sudah melampaui batas-batas logika, bisa merusak kehidupan sosial kemasyarakatan, maka hal ini menjadi haram. Kekhawatiran inilah yang melandasi penolakan terhadap liberalisasi pendidikan.

Ketiga, distorsi kepentingan. Setiap terjadi perubahan kebijakan, dengan sendirinya akan terjadi pergeseran kepentingan, begitu juga dengan dunia pendidikan. Ketika liberalisasi pendidikan diberlakukan, maka orientasi pendidikan akan berubah secara otomatis, mengikuti pola pendidikan yang dibawa masuk dari luar. Aspek ekonomi akan sangat berpengaruh, manajemen pendidikan akan menyesuaikan dengan trend pasar yang berkembang dan cenderung ke arah pencetakan profit atau keuntungan. Perubahan orientasi inilah yang dikhawatirkan oleh kalangan pendidik, karena jika hal ini terjadi, akan mengabaikan tujuan pendidikan nasional. Yaitu, melindungi segenap bangsa Indonesia, dan seluruh tumpah darah Indonesià, dan untuk memajukan-kesejahteraan umum, mencerdaskan kehidupan bangsa, dan ikut melaksanakan ketertiban dunia. Ketika itu terjadi, pembentukan jati diri dan ideologi bangsa, tidak bisa kita dapatkan lewat liberalisasi pendidikan. Dan yang ada, hanya menunggu kehancuran ideologi dan moralitas bangsa.

Era liberalisasi dan globalisasi semakin dekat, perkembangan dunia semakin maju dan kompleks, menjadi tantangan bagi bangsa kita, dan memaksa kita untuk berhadapan dengan era tersebut. Ide liberalisasi sebetulnya merupakan turunan dari ideologi kapitalisme. Inti dari ideologi kapitalisme adalah pengaturan ekonomi dan pembangunan diserahkan pada mekanisme pasar dan perusahaan-perusahaan swasta, guna mendapatkan keuntungan secara ekonomi, untuk mencapai kesejahteraan materiil. Menurut faham kapitalisme, yang dimaksud dengan kesejahteraan materiil meliputi pemenuhan kebutuhan dasar manusia (pangan, sandang, papan, kesehatan dan pendidikan) bagi setiap warga 
negara, penghapusan kemiskinan (poverty alleviation), tersedianya kesempatan kerja bagi seluruh rakyat untuk mendapatkan kehidupan layak (honest living) dan distribusi pendapatan dan kekayaan secara adil di antara warga negara.

Kalaupun liberalisasi pendidikan diterapkan, ada beberapa batasan tertentu, pendidikan asing yang bisa masuk ke dalam dunia pendidikan kita adalah pendidikan vocational dan pendidikan profesional. Dua bentuk pendidikan ini yang bisa diadopsi dalam dunia pendidikan kita, pendidikan vocational adalah pendidikan yang bersifat latihan kerja atau mempertinggi kemampuan peserta didik untuk menghadapiduniakerja. Sedangkan pendidikan profesional merupakan pendidikan bersifat khusus bagi profesi tertentu. Harus kita akui, dalam dua bidang pendidikan tersebut, kita sangat lemah dan tertinggal. Dunia pendidikan kita belum mampu mencetakindividuyang siap pakai. Dunia pendidikan kita hanya mampu mencetak individu yang teoritis, tanpa dibekali kemampuan praktikal yang memadai.

Kekhawatiran adanya liberalisasi terutama dalam pendidikan sangat beralasan, mengingat negara kita secara fundamental belum mampu mengimbangi arus globalisasi dan liberalisasi.

Dasar-dasar pendidikan kita belum cukup kuat untuk memasuki era tersebut (liberalisasi dan globalisasi).Maka, diperlukan pemahaman yang konsisten dan konprehensif untuk menata dan membangun sistem pendidikan yang berbasis kerakyatan, dan berorientasi pada penguatan ideologi bangsa:

Untuk memperkuat sistem pendidikan yang berbasis kerakyatan diperlukan kerja sama yang kuat dan konsisten antarlini pemerintahan, baik eksekutif, legislatif maupun yudikatif.

Nasionalisasi pendidikan harus dilaksanakan oleh pemerintah dalam.
Mengem bangkan dunia pendidikan ke depan, untuk mengimbangi arus liberalisasi dan globalisasi. Esensi dari nasionalisasi pendidikan adalah desentralisasi pendidikan. Pendidikan kita saat ini terlalu berpusat di kota-kota besar atau bertumpu di Pulau Jawa, sehingga penyebaran pendidikan belum sepenuhnya merata.

Sudah saatnya desentralisasi pendidikan dijalankan oleh pemerintah, sehingga dengan adanya desentralisasi ini diharapkan tidak ada kesenjangan pendidikan antara di pusat dan daerah. Yang diharapkan, pendidikan dapat terjangkau baik secara wilayah maupun ekonomi oleh masyarakat.

Nasionalisasi pendidikan mutlak diwujudkan pemerintah agar dunia pendidikan kita mengakar di seluruh rakyat. Rakyat bisa menikmati pendidikan secara adil dan merata, sehingga tidak timbul kesenjangan kualitas pendidikan dalam masyarakat. Sesuai dengan amanat Undang-undang Dasar 1945 pasal 31 ayat 1 , setiap warga negara berhak untuk memperoleh pendidikan dan pengajaran yang layak. Oleh karena itu, pemerintah harus mampu meningkatkan kualitas pendidikan, sehingga mampu menjadikan pendidikan sebagai bagian dari kehidupan masyarakat.

Pendidikan terbaik adalah pendidikan yang didambakan oleh seluruh lapisan masyarakat. Pendidikan terbaik tidak harus mahal, tetapi harus mampu mereduksi keinginan masyarakat untuk menikmati jenis dan kualitas pendidikan yang sama tanpa dibeda-bedakan. Dengan pendidikan yang baik dan layak, masyarakat (rakyat) mampu mengetahui dan memahami arus globalisasi dan liberalisasi secara benar. Rakyat diharapkan pula memahami sistem perpolitikan yang sehat dan dinamis, mampu berpikir cepat dan korektif, serta berperilaku santun, sehingga mampu menjadi individu yang berkualitas bagi bangsa. 


\section{Cikal Bakal Liberalisasi}

Kalau dirunut sejarahnya, liberalisasi bisa ditarik jauh ke belakang melalui awal pembentukan General Agreement on Tariffs and Trade (GATT), pada 1948. Awalnya ini diberlakukan pada objek barang-barang industri. Kemudian pada 1995, GATT diubah menjadi World Trade Organization (WTO) dan merambah lebih jauh baik dari aspek kewilayahan maupun substansi kegiatan di dalamnya. Hal ini mencetuskan liberalisasi di segala bidang, termasuk pendidikan dan kesehatan.

Tentu saja hal ini mengundang prokontra. Mereka yang setuju, berpendapat hal ini akan mendongkrak daya saing masyarakat lokal. Sebaliknya, yang menentang berpendapat hal ini cuma menguntungkan negara-negara kaya, khususnya para pemilik modal. Namun, Indonesia sendiri termasuk negara yang turut serta menandatangani pembentukan WTO dan kemudian menjadi anggota.

Sebagai konsekuensinya Indonesia pun makin terbuka bagi segala produk asing. Pada awal tahun 2000, seiring pulihnya perekonomian Indonesia pascakrisis, institusi pendidikan asing, mulai dari prasekolah hingga perguruan tinggi, pun mulai berbondong-bondong masuk ke Indonesia.

Jumlah penduduk dan potensi ekonomi masyarakat Indonesia, tentunya yang berada di golongan A plus, menjadi 'magnet' yang membuat penyelenggara pendidikan internasional menjadikan negeri ini sebagai sasaran pasar.

Sekolah Tiara Bangsa yang berdiri pada 2001 menjadi salah satu sekolah berlabel global yang masuk pada jajaran pertama. High Scope Indonesia, juga termasuk pada kelompok perintis. Sekolah berlisensi Amerika Serikat (AS) yang digagas Antarina
SF Amir itu sebenarnya telah masuik pada 1996, namun baru sebatas kelas prasekoiah. Baru pada era2000-an, High Scope membuka SD dan SMP. Beberapa bulan mendatang lembaga ini akan membuka SMA, yang dibangun bersebelahan dengan kompleks bangunan SD dan SMP di kawasan Simatupang Jakarta Selatan.

Kini, jumlah sekolah yang mengusung label global itu terus menjamur. Depdiknas sendiri sebenarnya tak pernah secara langsung mendata dan mengatur jenis sekolah ini. Peraturan Pemerintah (PP) Standar Pendidikan Nasional No 19/2005 yang menjadi acuan utama penyelenggaraan pendidikan nasional tak menyinggung eksistensi mereka secara langsung.

Hingga saat ini aturan yang digunakan adalah UU Sistem Pendidikan Nasional (Sisdiknas) No 20 Tahun 2003 yang menyebutkan bahwa institusi asing boleh masuk ke Indonesia dengan syarat harus menjalin kerja sama dengan mitra lokal. Itu yang menjadi dasar hukumnya, syarat utamanya adalah afiliasi lokal dan itu akan tetap dipertahankan," kata perwakilan Depdiknas dalam WTO Adjisuksmo kepada Media.

Ketentuan itu, berlaku untuk seluruh jenjang pendidikan, termasuk pendidikan tinggi. Sejauh ini, kata Adjisuksmo, pola afiliasi yang banyak dianut adalah kelas internasional. Universitas Indonesia (UI) dan Swiss German University (SGU) adalah beberapa kampus yang membuka kelas ini. Mahasiswanya belajar selama dua tahun di Indonesia dan selanjutnya terbang ke kampus yang menjadi mitra di Amerika, Australia, Swiss, Jerman, serta negara lainnya. Setelah pulang ke Indonesia, mereka berhak menyandang dual degree, gelar ganda. Gelar pertama diraih dari kampus lokal, sedangkan status Bachelor 
diperoleh dari luar negeri. Biaya mahal, yang mayoritas ditetapkan dalam kurs dolar, harus membuat calon mahasiswa waspada. Adjisuksmo mengingatkan, kendati pemerintah turut mengawasi, kewaspadaan masyarakat untuk menyeleksi akreditasi institusi lokal maupun yang menjadi mitra di luar negeri adalah keharusan.

\section{Liberalisme Wajib ditolak}

Menanggapi invasi perguruan tinggi asing ini, Rektor UGM Sofian Effendi meminta kepada pemerintah untuk berpikir kembali mengenai liberalisasi pendidikan.

Sebab, hal ini akan membawa implikasi buruk. "Jangan bilang bahwa liberalisasi sebagai bagian dari globalisasi itu tidak bisa ditolak, tetapi kalau kita mau pasti bisa. Yang pasti pemerintah harus benar-benar berhati-hati dalam masalah ini," kata Sofian kepada Media di ruang kerjanya.

Menurut Sofian, dengan diberlakukannya GATT, pemerintah telah melakukan perubahan paling mendasar terhadap tujuan pendidikan. Pendidikan, lanjutnya, bukan lagi merupakan suatu kegiatan kebudayaan untuk memanusiakan manusia, tetapi telah berubah menjadi kegiatan industri atau komoditas ekonomi. "Artinya pendidikan akan menjadi lahan untuk mencari keuntungan sebesarbesarnya, dan pada akhirnya biaya pendidikan di Indonesia akan semakin mahal," tegasnya.

Sofian juga menegaskan, upaya untuk mencapai salah satu tujuan nasional, yakni cermendaskan kehidupan bangsa akan semakin sulit dilakukan. "Liberalisasi perdagangan jasa pendidikan tinggi tersebut dilandasi motif neo-imperialisme untuk terus menguasai dan mengontrol negara berkembang. Apakah dengan kondisi untuk terus menguasai dan mengontrol negara berkembang. Apakah dengan kondisi ini tujuan pendidikan akan bisa tercapai?" kata Sofian dengan nada tanya.

Selain itu, lanjut Sofian, jika liberalisasi pendidikan dilakukan akan banyak perguruan tinggi di Indonesia yang tidak siap. Dan mereka akan menjadi sasaran empuk bagi perguruan tinggi asing (PTA) untuk menancapkan kekuasaannya di Indonesia. "Kalau saya bicara UGM pasti siap, tetapi kita tentu tidak bisa hanya memikirkan UGM saja. Kita harus berpikir Indonesia secara umumnya," katanya.

Jika alasan pemerintah meliberalisasi pendidikan adalah untuk meningkatkan kualitas pendidikan, menunut Sofian hal itu juga tidak tepat. Ditambahkannya, peningkatan kualitas bisa dilakukan dengan intemasionalisasi, yakni bekerja sama dengan PTAnamun dalam posisi yang sejajar dan saling menguntungkan.

Untuk itu, Rektor UGM ini kembali menegaskan penolakan terhadap liberalisasi. Para pimpinan PT yang masih tidur lelap saya gebrak-gebrak untuk mengambil sikap yang sama yakni menolak liberalisasi," tegas Sofian.

Saat ini, Forum Rektor Indonesia (FRl) dan Majelis Rektor Perguruan Tinggi (MRPTN) secara resmi telah menyatakan penolakan WTO. UGM sendiri, menurutSofian dan FRI juga telah membuat pemyataan yang dikirim ke UNICEF dan pemerintah. FRI, kata Sofian, juga akan meminta waktu untuk bertemu dengan presiden untuk secara khusus menyampaikan masalah ini. Pertemuan ini menurutnya penting karena sejauh ini, menurut pandangan Sofian, ada kesan pemerintah lebih condong untuk membuka keran liberalisasi.

Pandangan budayawan yang juga sineas Garin Nugroho, di era globalisasi, masuknya perguruan tinggi asing ke Indonesia memang tidak dapat dihindarkan. Sejauh di dalam kurikulum mereka 
pendidikan tentang budaya lokal tetap diberi ruang, hal tersebut tidak menjadi masalah. "Tetapi,persoalannya kan sekarang saja pendidikan tentang budaya lokal masih diabaikan. Strategi kebudayaan kita masih belum mampu melindungi budaya lokal. Barangkali, hal ini harus terlebih dahulu dibenahi," ujarnya kepada Media di Jakarta, beberapa hari silam.

Menurut Direktur Yayasan Sains dan Etika yang juga seorang sineas itu, sangat berbahaya jika strategi kebudayaan lokal belum mampu melindungi budaya lokal perguruan tinggi asing sudah masuk. "Bisabisa atas nama pasar bebas, maka etika terabaikan. Kita cuma menelan mentahmentah apa yang diajarkan dan diberikan oleh mereka. Karena kita memang tidak dilandasi dengan penguasaan kebudayaan lokal. Akibatnya, kita nanti cuma jadi bangsa yang konsumtif. Kita hanya menjadi konsumen dari perguruan tinggi asing semata," ujarnya.

Tanpa strategi kebudayaan lokal yang jelas, negara ini hanya akan menjadi neoliberalisme. Hadirnya perguruan tinggi asing di Indonesia hanya menjadikan masyarakat konsumtif, tidak produktif. "Kita hanya akan memiliki kebanggaan bisa sekolah di sekolah asing, tetapi tidak mampu menciptakan pendidikan yang setara dengan apa yang mereka buat," ungkap Garin Nugroho.

Jika itu terjadi, kata Garin, Indonesia bisa kehilangan segalanya. "Sekarang saja yang terjadi sudah begitu. Buah-buahan banyak yang masuk dari Thailand atau Malaysia. Pekerja iklan masuk dari negaranegara tetangga. Padahal, kita punya sumber dayanya. Itu karena selama ini strategi kebudayaan lokal kita memang tidak jelas. Ini yang mengkhawatirkan, Garin mengakui, di era pasar bebas, kehadiran produk asing termasuk perguruarí:tinggi asing ke Indonesia memang tidak bisa dihindarkan. Namun, memang perlu ada strategi kebudayaan lokal yang jelas. "Jangan sampai budaya lokal kita hilang dengan masuknya perguruan tinggi asing ke Indonesia," ujarnya.

Selain fasilitasnya lebih baik, karena memang sekolah ini mengacu pada standar internasional yang diterapkan di Amerika Serikat (AS), metode pembelajaran yang diterapkan membuat saya tersadar bahwa metode yang digunakan selama ini butuh banyak perbaikan.

Pada masa lalu, kita terbiasa mengajar satu arah, guru ceramah dan anak-anak mendengarkan. Tapi di High Scope kita ditraining untuk menyiapkan anak didik tidak hanya pandai menghafal namun juga piawai mengambil keputusan, berpikir analitis, dan memiliki jiwa kepemimpinan.

Kendati High Scope merupakan sekolah lisensi dari AS, di sini kita berupaya agar anak-anak tak kehilangan akar. Mereka tetap belajar agama, tata krama, dan budaya asli masyarakat Indonesia. Di sini ada piano sekaligus juga angklung. Jadi, anggapan. bahwa sekolah internasional akan mengikis jati diri anak Indonesia, tak terjadi di High Scope.

Sebagai pendidik, saya sarankan bagi orang tua untuk pandai-pandai memilih sekolah. Jika memang mampu menyekolahkan anak di tempat yang mengacu pada standar internasional, teliti betul kurikulum dan sistem pembelajaran yang diterapkan.

Kita harus menyiapkan anak-anak tak sekadar pintar, asertif, cerdas secara emosional, namun tetap mengakar pada tradisi setempat. Pasalnya, menyekolahkan anak di sekolah sekelas High Scope memang tidak murah. Sehingga kita harus benar-benar yakin dengan kualitasnya. 
High Scope tidak mengukur kemampuan anak berdasarkan angka semata. Kita menilai anak dengan deskripsi menyeluruh tentang perkembangan yang berhasil dilewatinya. Dalam satu kelas, anak-anak dikelompokkan berdasarkan kemampuannya. Sehingga pekerjaan yang harus diselesaikannya pun tidak sama.

Anak tidak hanya bergantung pada guru untuk bertanya, tapi bisa juga belajar dari teman-temannya.

High Scope juga tak pernah memvonis anak tidak mampu dengan menetapkan anak tertentu tidak naik kelas. Semua anak dibimbing sesuai kondisi dan kemampuannya. Di sekolah ini juga tak ada deretan bangku, anak-anak duduk melingkar maksimal 24 orang dalam satu kelas. Mereka juga boleh memilih untuk duduk di karpet. Semua pilihan dan pendapat anak dihargai dan didengarkan oleh guru maupun teman-temannya.

Akan lebih baik jika paradigma pendidikan yang diterapkan High Scope juga diadopsi oleh sekolah lain atau bahkan menjadi kurikulum baku nasional.

Sehingga semua anak bisa berkembang optimal, menjadi generasi baru yang percaya diri dan mampu berpikir cerdas.

Sophia Latjuba mengatakan: Sekolah buat saya adalah investasi. Saya akan melakukan apa pun untuk memastikan anak saya Eva Celia Lesmana memperoleh pendidikan terbaik. Memilih sekolah nasional plus yang berstandar internasional, jelas tidak murah.

Kadang saya merasa agak berat juga, apalagi saya sempat menjadi orang tua tunggal. Namun, pengorbanan materi itu terbayar ketika melihat perkembangan akademik Eva. Belum lagi dengan kemajuan personality-nya. Eva kini tidak malu-maiu, baik itu untuk berbicara maupun berbuat.
Perjalanan saya menemukan sekolah yang benar-benar tepat untuk Eva cukup panjang dan melelahkan. Eva sempat tiga kali keluar masuk SD. Sampai akhirnya saya memutuskan untuk mendaftarkan Eva di High Scope. la masuk ke High Scope pada September 2004 pada grade empat.

Sebelumnya Eva juga bersekolah yang juga berlabel nasional plus. Tapi, karena saya tak teliti ternyata sistem pembelajaran yang diterapkan kurang baik, buktinya akademik Eva menurun bahkan ia enggan pergi ke sekolah.

Oleh karena itu, saya' sarankan orang tua lain untuk pintar-pintar memilih sekolah. Walaupun namanya sekolah internasional atau nasional plus, kita harus meneliti betul bagaimana sistem pembelajarannya. Jangan asal memilih sekolah karena bergengsi, padahal sistemnya kurang baik buat anak kita.

Saya merasakan betul bagaimana menjadi murid sekolah negeri dengan sistemnya yang konvensional. Kalau kita tak bisa menjawab pertanyaan guru, kita dimarahi. Tapi, di sekolah Eva, kesalahan bukanlah aib namun menjadi pemicu agar anak semakin memperbaiki diri.

Kebetulan di High Scope ini saya maupun Eva merasa cocok, dan hasilnya terlihat nyata pada diri Eva. Karena, saya amati High Scope bukan cuma melulu meningkatkan kualitas akademik anak, namun juga kepercayaan diri mereka. Hal itu tak kalah pentingnya buat anak. Mudahmudahan sistem yang diterapkan High Scope dan sekolah-sekolah nasional plus lainnya, yang menerapkan metode pembelajaran dengan bagus bisa juga diterapkan di sekolah biasa. Jadi, bukan hanya anak-anak berpunya saja yang bisa menikmati asyiknya belajar di sekolah yang bagus. Lebih baik lagi kalau pemerintah juga 
tidak membiarkan begitu saja sekolahsekolah nasional plus ini. Walau bagaimana, bantuan dari pemerintah juga penting. Sehingga beban orang tua juga tidak terlalu berat.

\section{Jalur Bengkok Liberalisasi Pendidikan}

Dunia pendidikan kita, selalu saja berada dalam jalur tak lempang, tak lurus, penuh lubang, dan berada pada titik jalur bengkok. Jalur tak lempang, penuh lubang, dan bengkok ini, adalah khas pembangunan pendidikan yang dibangun dengan ribuan prasangka, penuh curiga, dan selalu berdiri pada pilar-pilar ketidakpercayaan pada sumber daya manusia, yang lahir dan tumbuh dari tubuh Indonesia itu sendiri.

Akibatnya, produk yang dilahirkan dari sistem penuh curiga dan saling tak percaya ini, adalah generasi tanpa identitas. Generasi compang-camping, yang bergerak tanpa inspirasi, tanpa imaji-imaji liar, meski tetap berada pada titik-titik yang konstruktif.

Tengok saja, kemauan pemerintah dalam mengusung liberalisasi pendidikan. Liberalisasi yang akan digulirkan tidak akan dilakukan secara penuh, setengah hati. Liberalisasi yang ditawarkan adalah liberalisasi bersyarat. Perguruan tinggi asing (PTA) yang masuk ke Indonesia, ada beberapa syarat yang harus dipenuhi. Syarat yang diajukan antara lain, PTA yang beroperasi harus bekerja sama dengan perguruan tinggi dalam negeri, yang sudah terakreditasi.

Selain itu, PTA hanya boleh mempunyai modal atau saham sebesar $49 \%$. Bahkan kota yang boleh menerapkan liberalisasi. Selain itu, kota yang diperbolehkan untuk operasi PTA hanya dibatasi kota-kota seperti Jakarta, Bandung, Yogyakarta, dan Medan.
Sejatinya, liberalisasi harus mämpu menggambarkan prinsip-prinsip yang menekankan kebebasan pribadi, dan pembebasan dari struktur sosial-politik yang menindas. "Liberal" seharusnya juga menggandeng dua makna mendasar; kebebasan dan pembebasan.

Dengan pola pembatasan dan prasyarat-prasyarat PTA di Indonesia, sulit ditemukan dua substansi dari isu liberal itu, kebebasan dan pembebașan.

Dominasi kekuasaan pemerintah dan politik harus dipisahkan. Liberalisasi pendidikan, seharusnya menolak peran negara yang terlalu dominan, dan menyerahkan kepada publik untuk memilih hak pendidikan tanpa ada prasyaratprasyarat. Liberalisasi' pendidikan harus bersandar dan berpijak pada aspirasi publik, bukan aspirasi kekuasaan. Jika publik merasa serbuan PTA sebagai ancaman dan gangguan, serta menggerogoti kantongkantong pribadi, seharusnya negara juga melihat dari persepsi ini. Jika liberalisasi pendidikan adalah sumber inspirasi yang bisa memengaruhi kebijakan publik, terutama pada sektor ekonomi, seharusnya negara tidak punya hak suci untuk menentukan segala bentuk kebijakan publik. Memilih pendidikan berada dalam ruang privat, dan urusan publik harus diselenggarakan melalui proses konsensus. Ada baiknya kita mendengar pikiran yang digulirkan Rektor UGM Sofian Effendi.

Bagi Sofian, liberalisasi pendidikan tinggi tetap akan membawa dampak buruk bagi dunia pendidikan Indonesia. Akan banyak perguruan tinggi domestik yang dipastikan gulung tikar karena tidak bisa bersaing. Selain itu, liberalisasi pendidikan tinggi, akan menjadikan masyarakat Indonesia semakin sulit untuk mendapatkan akses pendidikan karena mahalnya biaya. 
Inilah jalur bengkok liberalisasi pendidikan Indonesia, tak jelas, samar-samar, dan masih berada pada ambang bawah sadar masyarakat.

\section{Pelecehan Martabat Bangsa}

Liberalisasi pendidikan merupakan pengkhianatan terhadap UUD dan pelecehan martabat bangsa. Demikian ditegaskan pengamat politik dan ekonomi, ichsanudin Noorsy, saat ditemui di sela-sela Konferensi Nasional "Pendidikan Nasional dalam Arus Neoliberalisme", di Unpad.Ichsanudin mengatakan, pemerintah memiliki amanat yang harus dijaiankan dalam bidang pendidikan ini yang termaktub pada pasai 31 UUD 1945, Tap MPR, dan UU Sisdiknas. Jika pemerintah melihat pendidikan sebagai barang komersial, artinya pemerintah menyimpang dari konstitusi, karena tugas penyelenggara negara adalah mencerdaskan kehidupan masyarakat."Jika pemerintah mengatakan bahwa dunia sudah menjadi liberal dan global, bukan artinya kita harus ikut menjadi liberal dan global juga," ujamya.la mengatakan, kata liberal dan global harus diwaspadai. Liberal biasa diterjemahkan sebagai kekuatan modal finansial dan menggeser barang-barang publik menjadi barang-barang komersial. Sedangkan kata global biasa diterjemahkan, menjunjung tinggi asas individual. Padahal dalam UUD 1945 tersirat makna bahwa negara dan bangsa indonesia tidak berpihak kepada kekuatan individu. Justru sebaliknya berpihak kepada kekuatan nasional dan sosial, dengan menjunjung tinggi hak individu.Artinya, demikian Ichsanudin, negara harus bertanggung jawab sepenuhnya dalam proses mencerdaskan bangsa. Ini harus diterjemahkan melalui anggaran yang besar untuk pendidikan. "Kalau kita lihat untuk periode sekarang, dari biaya total anggaran yang diusulkan oleh Mendiknas terdahulu dan kemudian diturunkan, kemudian di APBNP kembali kepada usulan Mendiknas, jumlahnya cuma $7,08 \%$ dari total anggaran. Negara-negara lain, di atas itu. Bahkan jika dibandingkan PDB, anggaran pendidikan kita cuma $1,56 \%$, negara lain bergerak antara $3,5-5 \%$ terhadap PDB," ujarnya.Menurutnya, sebenarnya pemerintah memiliki uang untuk membiayai pendidikan ini, andaikan uang tersebut tidak dipakai untuk membayar utang luar negeri baru."Kita terlampau berani mengambil utang baru sehingga meninggalkan kewajiban untuk mencerdaskan masyarakat. Saya menyebut utang sebagai kejahatan kemanusiaan. Kalau kita merasa sebagai bangsa yang berdaulat dan merdeka, tekanan negara mana pun harus bisa kita antisipasi," ujamya.la mengatakan, sepanjang pemerintah berpihak kepada kekuatan-kekuatan neoliberal, maka yang terjadi adalah tersingkirnya peran negara untuk mencerdaskan kehidupan masyarakat. Kekuatan neoliberal itu terdiri dari empat aspek yakni, mendorong kekuatan individu, mendorong mekanisme pasar, masyarakat diiming-imingi program karikatif, pasar dianggap sebagai pengambil keputusan paling bijaksana." Indikator tersingkirnya peran negara dapat kita lihat jika masyarakat berteriak akan dua hal yakni, mahalnya biaya pendidikan dan mahalnya biaya kesehatan," ujarnya.Di sisi lain masyarakat dan pemerintah harus paham mengenai maraknya kampanye globalisasi. Globalisasi, ujar Ichsanudin Noersy, bisa diterjemahkan menjadi lima hal yakni; Amerikanisasi, hegemoni Amerika, dominasi Amerika, imperialisme Amerika, dan upaya untuk terus melanjutkan imperium Amerika. Juga harus dipahami, dari penelitian gerakan neoliberal di empat negara, semuanya hanya menghasilkan 
kerusuhan sosial dan tekanan kepada neraca pembayaran.Harus diantisipasi Pembantu Rektor Bidang Akademik Universitas Diponegoro Sudharto P. Hadi mengatakan, pemerintah harus mengantisipasi liberalisasi pendidikan yang semakin menggejala di tanah air agar tujuan awal meningkatkan kualitas pendidikan serta sumber daya manusia (SDM) masyarakat Indonesia akan terlaksana. Pemerintah tidak cukup hanya dengan meluncurkan perangkat perundangan baik undang-undang (UU) maupun peraturan pemerintah (PP). Lebih dari itu, juga harus menyiapkan berbagai strategi dan kebijakan agar perguruan tinggi (PT) di tanah airmemiliki posisitawardengan $P T$ asing serta Organisasi Perdagangan Dunia (WTO). "Dengan begitu, lembaga pendidikan kita tidak sekadar menjadi penonton tetapi berperan aktif di dalamnya," ucapnya.Peningkatan posisi tawar itu, menurutnya, dapat dilakukan melalui kerja sama berbasiskan Tri Dharma Perguruan Tinggi di antara PTN dan PT dengan networking di tingkat regional dan antarregional. "Tak perlu lagi ada dikotomi PTN dan PTS," ujar Sudharto. Sudharto menambahkan peningkatan mutu dan manajemen bukan hanya dilakukan pada skala nasional, namun juga dilakukan di tingkat internasional agar PT di tanah air dapat bersaing.la menjelaskan liberalisasi pada mulanya dicetuskan melalui General Agreement on Tariffs and Trade (GATT) dengan objek barang-barang industri. Kemudian pada 1995, GATT diubah menjadi. WTO dan merambah lebih jauh baik dari aspek kewilayahan serta substansi kegiatan di dalamnya.Indonesia sendiri termasuk negara yang turut serta menandatangani pembentukan WTO dan kemudian menjadi anggota. "Tujuan GATT sebenarnya sangat mulia yakni di samping mewujudkan liberalisasi progresif dari perdagangan jasa. Namun juga mendorong pertumbuhan ekonomi dan pembangunan serta meningkatkan peran serta negara-negara berkembang sehingga harus muncul posisi tawar dan daya saing negara-negara di dalamnya. Inilah tantangannya," paparnya.

\section{Kewajiban Negara Mencerdaskan Bangsa}

Pada konferensi nasional tentang pendidikan nasional dalam arus neoliberalisme yang berlangsung di Universitas Padjadjaran Bandung beberapa waktu yang lalu, terungkap beberapa pemikiran kritis yang intinya merasa khawatir tentang masa depan pendidikan kita. Liberalisasi pendidikan dinilai merupakan pengkhianatan terhadap UUD 1945. Konstitusi menekankan bahwa tugas utama negara adaiah mencerdaskan bangsa. Amanat konstitusi inilah yang sampai sejauh ini menjadi masalah yang tetap sangat krusial, sehingga masyarakat pun harus menanggung akibatnya. Dengan alasan anggaran negara yang belum memadai pemerintah terus menerus berkilah belum mampu memenuhi tuntutan agar bidang pendidikan memperoleh anggaran setara $20 \%$ APBN. Akibatnya, dunia pendidikan kita benar-benar tersungkur. Gaji guru kecil, fasilitas sekolah tidak memadai, bahkan di beberapa tempat berlangsung proses pendidikan yang sangat tidak memenuhi standar kelayakan.Sudah cukup banyak pakar pendidikan kita yang mengemukakan bahwa bidang pendidikan indonesia sangat tertinggal jauh dibanding tetangga-tetangganya di ASEAN sekalipun. Dengan mutu pendidikan seperti itu, bagaimana kita akan mampu bersaing? Namun, alih-alih berusaha menyediakan anggaran yang memadai, pemerintah bahkan melangkah ke arah yang sebaliknya, yakni mendukung langkah komersialisasi pendidikan, antara lain di bidang pendidikan tinggi.Pendidikan, di samping kesehatan, adalah hak warga negara yang paling 
mendasar. Negara harus mengindahkan hal ini secara sungguh-sungguh. Dengan kata lain, alasan apa pun yang menolak pemenuhan hak warga negara yang satu ini, sebenarnya tidak bisa ditoleransi. Batas standar harus diupayakan secara optimal. Ketentuan wajib belajar (wajar) sembilan tahun sudah lama disepakati. Namun, dalam pelaksanaannya masih terkatung-katung. Maka merupakan suatu reaksi yang wajar jika dalam kondisi seperti itu masyarakat bereaksi sangat kritis terhadap kecenderungan liberalisasi pendidikan. Ada rasa khawatir, jika kebijakan demikian benarbenar dilaksanakan jangan-jangan derajat bangsa ini akan terjerembab ke titik nadir yang paling rendah.Semua pihak sebenarnya sama-sama menyadari bahwa pemerintah kita saat ini berada dalam posisi sulit karena harus menghadapi tantangantantangan yang tidak ringan. Tapi, seberat apa pun tantangannya secara etis jangan sampai pemerintah mengorbankan nilai-nilai yang sangat esensial, khususnya masalah pendidikan.Komersialisasi bidang-bidang yang berkaitan erat dengan hak-hak publik, seperti bidang pendidikan, tentu tidak akan dipandang sebagai sebuah aib yang berat jika kondisi masyarakat sudah mendukungnya. Bagi sebuah masyarakat yang sudah sejahtera dan maju, murah atau mahalnya ongkos yang harus dipikul untuk memenuhi hak-hak dasar dalam menjalani hidup sehari-hari akan menjadi sangat relatif. Meskipun demikian, bangsa-bangsa yang sudah majulah yang justru berusaha secara sungguh-sungguh memberikan layanan yang lebih memadai kepada masyarakatnya. Bidang pendidikan dan kesehatan biasanya menjadi prioritas utama yang ditanggung oleh negara.Di Indonesia, ada kecenderungan yang sebaliknya. Negara seperti dengan sengaja ingin mengabaikan kewajiban-kewajiban sosialnya. Tudingan ini akan makin kencang dan makin keras jika komersialisasi pendidikan benar-benar dijalankan. Di balik itu ada kesan yang kuat, sebagaimana mengemuka dalam acara konferensi nasional tentang pendidikan nasional dalam arus neoliberalisme di atas. Pemerintah dicurigai mengikuti begitu saja apa yang disarankan oleh pemerintahan yang sedang berkuasa di Washington sekarang. Pengaruh Amerika memang sangat kuat terhadap Jakarta dan itu sudah lama samasama kita rasakan. Polemik tentang kepatuhan kita menjalankan saran-saran yang ditawarkan IMF dalam menyelesaikan krisis ekonomi tempo hari misalnya sampai sekarang masih berbuntut panjang. Kita dianggap mengambil langkah yang salah dengan cara menurut sepenuhnya. Apalagi Malaysia yang justru tidak mengikuti saran IMF ternyata bisa lebih cepat mengatasi krisisnya.PenutupKalau dalam kasus ekonomi saja akibatnya sedemikian parah, apalagi jika benar dalam bidang pendidikan pun kita mengikuti begitu saja saran atau konsep yang dibuat di Washington. Sikap kritis yang dimaksudkan untuk menolak liberalisasi pendidikan, sebagaimana dikemukakan para pakar dengan argumen yang kuat pula itu, pada tempatnyalah kalau juga ditanggapi secara kritis. Masyarakat tidak ingin menerima kebijakan pemerintah dalam bidang pendidikan yang akan menimbulkan beban lebih berat di masa yang akan datang.

\section{Daftar Pustaka}

Abel, Christopher, and Colin Lewis.1993. Welfare. Poverty and Development in Latin America. London: Macmillan.

Aglietta, M. 1982. "World Capitalism in the 1980s." New Left Review 136 (novDec.):5-41. 
Anderson, Perry. 1979. Lineages of the Absolutist State. London: Verso.

Assegaf, Abdurrahman. 2003. Internasionalisasi Pendidikan: Sketsa Perbandingan Pendidikan di Negara-negara Islam dan Barat. Yogyakarta: Gama Media.

Barnet, Richard, and John Cavenagh. 1994. Global Dreams: Imperial Corporations and theNew World Order. New York: Simon \& Schuster.

Francis Wahono,. 2001. Kapitalisme Pendidikan, Antara Kompetisi dan Keadilan, Yogyakarta: Insist Press, Cindelaras Bekerjasama dengan Pustaka Pelajar.

Kim, W. Chan, Mauborgne, Renee. 2005. Blue Ocean Strategy: How to Create
Uncontested Market Space and Make the petition Irrelevant, Harvard Business

School Publishing Corporation, Boston

Mark Olssen, John Codd and Anne-Marie O'Neill. 2004. EducationPolicy:Globalization, Citizenship and Democracy, London: Sage Publications.

Spero, Joan Edelman. 1981. The Politics of Intemational Economic Relations, $2^{\text {nd }}$ edition, New York: St. Martin Press.

Stiglitz, Joseph. 2001. Globalisation and lis Discontents, New York: WW Norton. 